Acta Technologica Agriculturae 3

Nitra, Slovaca Universitas Agriculturae Nitriae, 2015, pp. 88-91

\title{
CROP RESIDUES DISTRIBUTION AFTER TILLAGE OPERATIONS UNDER CONTROLLED AND RANDOM TRAFFIC TECHNOLOGY
}

\author{
Miroslav MACÁK*, Jana GALAMBOŠOVÁ, Vladimír RATAJ, Martin INGELI, \\ Božena VITÁZKOVÁ, Jozef ĎUĎÁK, Miroslav ŽITŇÁK \\ Slovak University of Agriculture in Nitra, Slovak Republic
}

\begin{abstract}
Controlled traffic farming is a technology used to avoid soil compaction introduced by field machinery load and traffic. The benefits in improved soil conditions and yield increase were shown in Australia, the US and some parts of Europe. The use of permanent tramlines for every field operation was considered as a barrier to implementation in some parts of Europe. This was mainly due to fear from tillage quality in terms of crop residues distribution. The paper reports the results of the two-year assessment of the technology compared to traditional random traffic treatments in field scale experiments. The spring barley and oilseed rape crops were grown. Measurements were taken after the stubble breaking tillage operation with the Lemken disc harrows. Image analysis was used to calculate the distribution of crop residues. Results showed that the use of permanent tramlines has no negative influence on crop residues distribution.
\end{abstract}

Keywords: image analysis; spring barley; oilseed rape

Extensive traffic causes major problems of agricultural production due to increased compaction of soil. Consequently, soil compaction is one of the major problems facing modern agriculture (Hamza and Anderson, 2005). Soil tillage practices in terms of field traffic were recently described by Kroulík et al. (2009). Controlled traffic farming is a promising technology for soil compaction reduction with many crop and soil benefits (Chamen, 2011; Kingwell and Fuchsbichler, 2011). The technology is used mainly in Australia, America and Western Europe. Tullberg et al. (2007) reported that CTF covers an area exceeding 2 Mha in Australia. In terms of machinery selection and implement as well as track widths matching, local growing and legal requirements have to be respected. There is no universal solution for the configuration of traffic lines, and different models of field traffic layout are used in different parts of the world (Vermeulen et al., 2010).

Despite its benefits, global and especially European uptake of this technology is relatively slow (Tullberg et al., 2007). This may be due to the diversity of growing conditions, soils, crops, technologies and machinery management systems across this region. Recently, some research results of the technology have been published. These report benefits and drawbacks in Europe aimed at field efficiency (Galambošová and Rataj, 2011), yield changes (Anken et al., 2012; Demmel et al., 2012; Smith et al., 2014; Galambošová et al., 2014) and benefits of avoiding compaction (Chyba et al., 2013); however, there are no sufficient data reported on soil tillage quality. Mainly soil roughness and crop residues play an important role as these are the main concerns of farmers when willing to convert to CTF. The study on soil roughness was reported by Galambošová et al. (2012), the study on crop residues is discussed in the following sections. In the presented paper, we test the hypothesis that implementation of CTF does not cause difficulties in terms of crop residues distribution.

\section{Material and methods}

\section{Site characteristics}

A pair of fields at University Farm in Kolíňany near Nitra (Slovakia) with an average rainfall of $550-600 \mathrm{~mm}$ per year was selected for the study. A 16 ha field (18.207545, 48.371683) was selected for implementation of the controlled traffic farming study (Figure 1). As a control field (18.245434, 48.352499), a 20 ha part of a 90 ha field was selected (shown in Figure 1). Overall, soil texture can be classified as a loam soil, with the exception of southern part (sampling point 13) of the CTF field where it becomes clay loam in the 0.5-0.6 $\mathrm{m}$ depth profile.

\section{Controlled traffic farming field}

The controlled traffic system was implemented in spring 2009 while drilling spring barley, the details of which are described in Galambošová and Rataj (2010) and Galambošová et al. (2012). The machinery used for field operations is listed in Table 1 and these adhered to a $6 \mathrm{~m}$ OutTrac (Vermeulen et al., 2010) based on the machinery available.

Conservation tillage practices using the Lemken disc harrows were employed prior to drilling, as indicated in Table 1. The depth of the operation was up to $0.18 \mathrm{~m}$. Machinery guidance was provided by Trimble RTK Autopilot mounted 


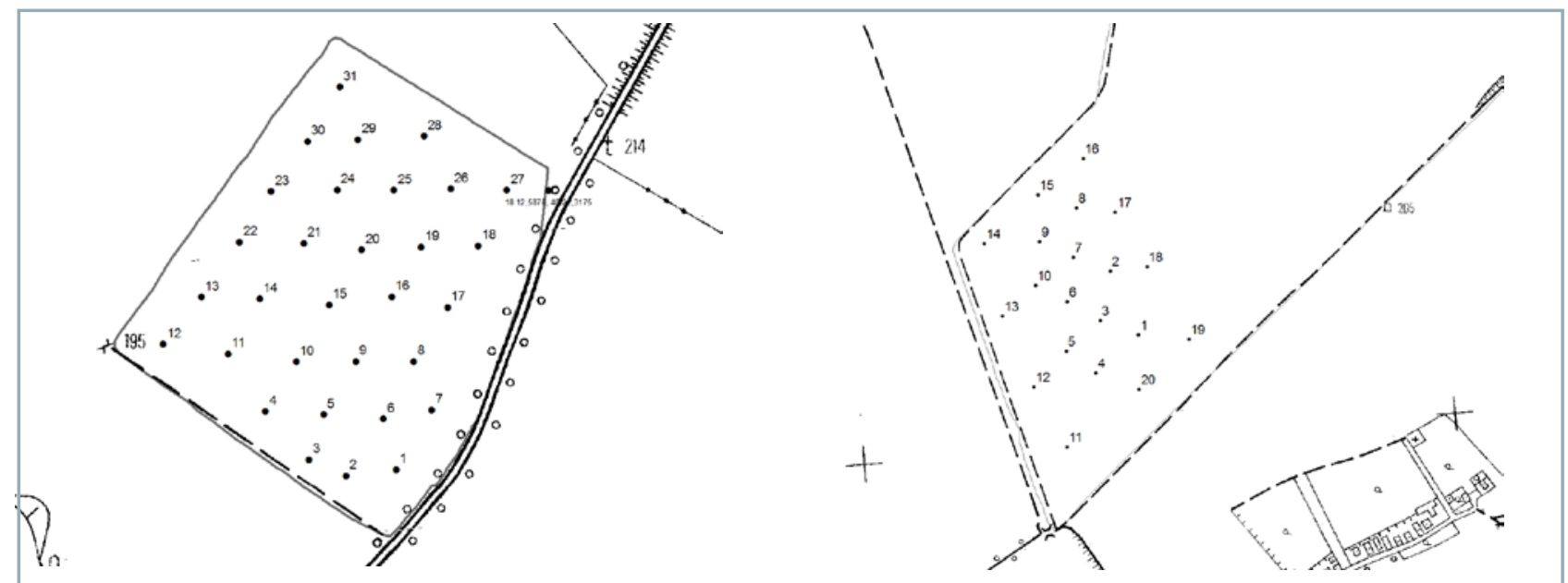

Figure 1 CTF and RTF field, layout of monitoring points

on a New Holland tractor and on a John Deere tractor with the satellite-based SF2 correction. The drift of the latter was compensated with a physical mark in the field and the software shift function before each operation. In terms of field operations, the CTF field was farmed using permanent tramlines.

Table 1 Machinery used for the experiment

\begin{tabular}{|l||c|c|c|}
\hline No. & Machinery & Operation & $\begin{array}{c}\text { Implement } \\
\text { width }\end{array}$ \\
\hline \hline $\mathbf{1}$ & $\begin{array}{c}\text { New Holland T 6070 + } \\
\text { Lemken Solitaire 9 }\end{array}$ & drilling & $6 \mathrm{~m}$ \\
\hline $\mathbf{2}$ & $\begin{array}{c}\text { New Holland T 6070 + } \\
\text { sprayer Agrio NAPA }\end{array}$ & spraying & $24 \mathrm{~m}$ \\
\hline $\mathbf{3}$ & Claas Lexion 480 & harvesting & $9 \mathrm{~m}$ \\
\hline $\mathbf{4}$ & $\begin{array}{c}\text { John Deere 8230 + discs } \\
\text { Lemken Rubin 9 }\end{array}$ & $\begin{array}{c}\text { stubble } \\
\text { tillage }\end{array}$ & $6 \mathrm{~m}$ \\
\hline $\mathbf{5}$ & $\begin{array}{c}\text { John Deere 8230 + } \\
\text { Lemken Sy-Compactor }\end{array}$ & $\begin{array}{c}\text { seedbed } \\
\text { preparation }\end{array}$ & $6 \mathrm{~m}$ \\
\hline
\end{tabular}

\section{Random traffic field}

The control field was managed typically for the region, conducting the operation under an angle to previous one, which is done in order to avoid roughness and improve crop residue distribution. The control field stands for the random traffic farming model - RTF field. To evaluate the machinery movement, a GPS receiver was installed in every machine used. The data were processed with the geographical information system ArcGIS (ESRI, US). The results are shown in Figure 2.

The results correspond well with the data published by Kroulík et al. (2009). The results showed that for the minimum tillage technology used in the RTF field, the nontrafficked area is on $22 \%$ of the total area of the field. The areas of $43.9 \%, 30.1 \%$ and $4.1 \%$ of the field were trafficked once, twice and three times during the season, respectively (Galambošová and Rataj, 2011). The operations were conducted under four angles.

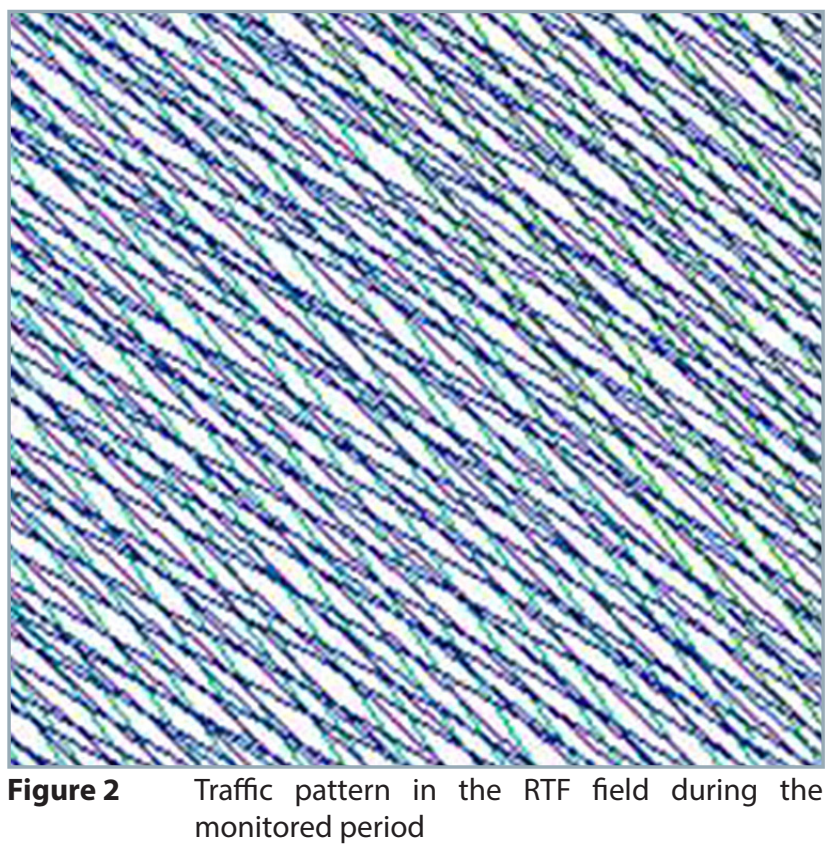

\section{Crop residues distribution}

Both fields used the same cropping rotation, agronomy and machinery. In the 2009 and 2010 growing seasons, experimental measurements were conducted growing spring barley (Hordeum sativum) and oilseed rape (Brassica napus) in both the CTF and RTF fields. The aim of measurements was assessing residues distributions, which are considered to be barriers to CTF adoption in Central European conditions.

Measurements were conducted after the tillage breaking operation. The crop yield was determined to remove the effect of different crop residual amounts for this study. Yield samples were taken at the monitoring points as given in Figure 1. The ANOVA statistics was used for the statistical analyses using the Statistica software (Stat Soft Inc., 1984-2011).

The crop residues distribution was conducted through the image analyses techniques. At selected monitoring points images were taken, which were later selected in 
Adobe Photoshop. The same sampling design was used as for the study above. The CTF field was assessed at 31 and 20 monitoring points in 2009 and 2010, and 20 monitoring points were used in the control field in both seasons. The images were taken randomly at each monitoring point 10 times. The IrfanView 3.51 software was used to turn the image into a black and white image. The calculation of the surface covered with crop residues (CR) was conducted using the Impor Basic 4.0 software (Kvant, s.r.o., Bratislava, Slovakia) and expressed as a percentage of the total area. The mean values of 10 images were used as representative values for each monitoring point.

\section{Results and discussion}

In order to compare the crop residues distribution in the CTF and RTF field, first of all, the information on yield was obtained. The data in Table 2 represent means and standard deviations for the samples located across the two fields. The ANOVA showed that the yield is variable within the field; however, the difference between the fields is not significant at $p<0.05$ in any of the years. Therefore, the amount of crop residues needed to be processed is comparable for the two fields.

The measurements of crop residues were conducted on $31^{\text {st }}$ July 2009 and on $4^{\text {th }}$ August 2010 . The example of image taken and its processing in the software is given in Figure 3.

Each picture was analysed, and the mean values for each field and season together with standard deviation are given in Table 3.

The ANOVA analyses showed that there was no significant difference $(p<0.05)$ between the two traffic patterns in either of the monitoring seasons although there was obviously a large difference between barley and oilseed rape (Table 3). The crop residues distribution corresponds with values reported by Mašek et al. (2012).
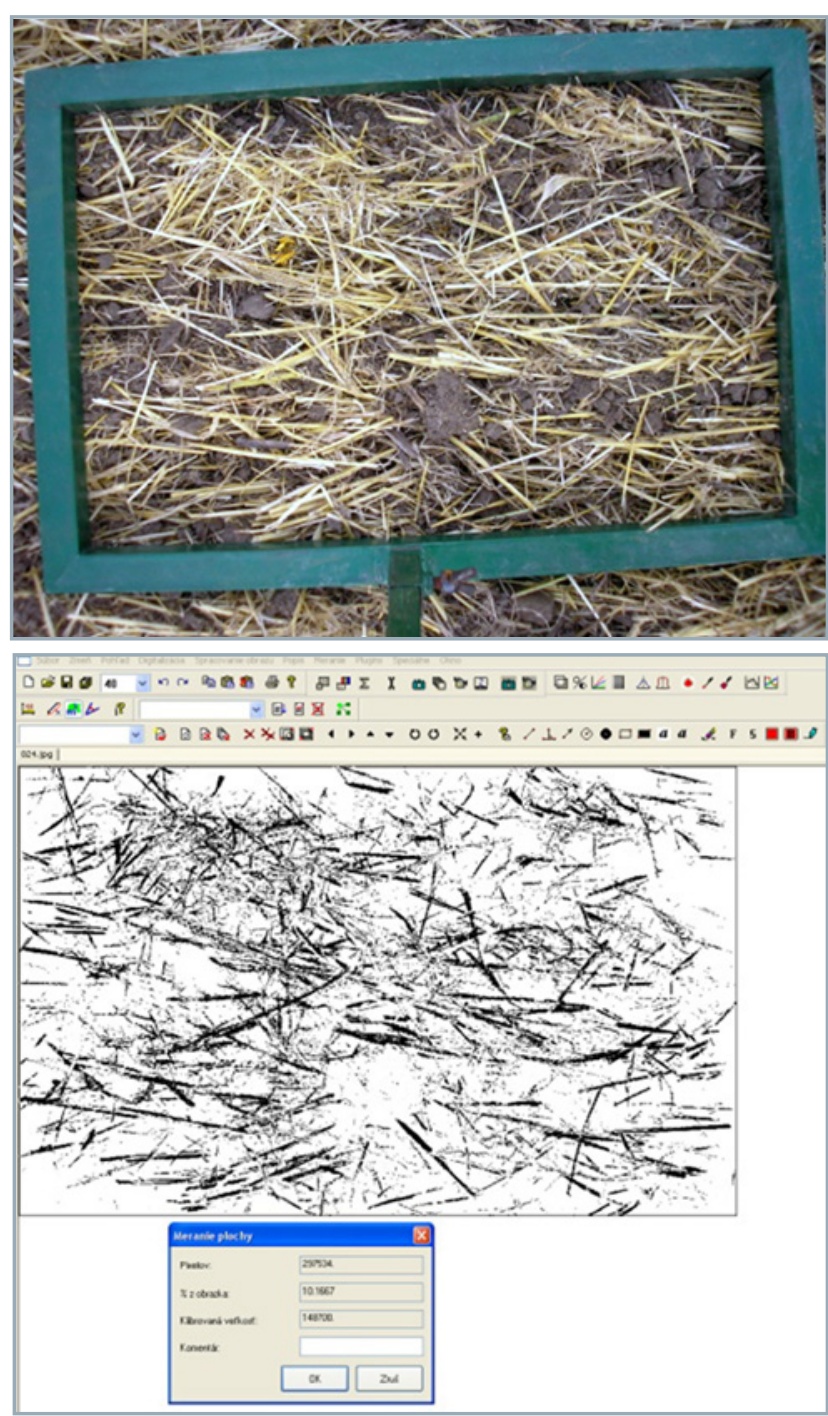

Figure 3 Image taken at a monitoring point and image processed in Impor Basic 4

Table 2 Crop yield parameters of spring barley and oilseed rape

\begin{tabular}{|l||c|c|c|}
\hline Year/crop & Traffic regime & Yield (mean \pm standard deviation) & Number of samples \\
\hline \hline \multirow{2}{*}{ 2009/spring barley } & CTF & $5.10 \pm 0.97$ & 31 \\
\cline { 2 - 4 } & RTF & $5.52 \pm 0.72$ & 20 \\
\hline \multirow{2}{*}{ 2010/oilseed rape } & CTF & $1.75 \pm 0.87$ & 135 \\
\cline { 2 - 4 } & RTF & $1.50 \pm 0.73$ & 45 \\
\hline
\end{tabular}

Table 3 Area of crop residues distribution in the monitored fields

\begin{tabular}{|l||c|c|c|}
\hline Year/crop grown & Field & Mean values for area of crop residues, $\%$ & Coefficient of variability, \% \\
\hline \multirow{2}{*}{ 2009/barley } & CTF & $21.57( \pm 8.89) \mathrm{a}$ & 41 \\
\cline { 2 - 4 } & RTF & $25.16( \pm 9.32) \mathrm{a}$ & 37 \\
\hline \multirow{2}{*}{ 2010/oilseed rape } & CTF & $5.95( \pm 1.4) \mathrm{b}$ & 23.58 \\
\cline { 2 - 4 } & RTF & $4.26( \pm 3.14) \mathrm{b}$ & 73.75 \\
\hline
\end{tabular}

$\mathrm{a}, \mathrm{b}$ - different letters stand for statistically different groups ( $L S D$ test, $p<0.05$ ); CTF - controlled traffic farming, RTF - random traffic farming 


\section{Conclusions}

Obtained results showed that there was no significant difference $(p<0.05)$ between the two traffic patterns in either of the monitoring seasons although there was obviously a large difference between barley and oilseed rape. However, further assessment should be conducted for different soil types and tillage practices.

\section{Acknowledgements}

This paper was prepared in the frame of the research project funded from the European Union under the title: ITEPAg Application of Information Technologies to Increase the Environmental and Economic Efficiency of Production AgroSystem. ITMS 26220220014. www.itepag.uniag.sk

\section{References}

ANKEN, T. - HOLPP, M. - REK, J. - WEISSKOPF, P. 2012. Soil and crop responses to controlled traffic farming in Switzerland. In Agrociencia Uruguay, special issue 2012.

DEMMEL, M. - BRANDHUBER, R. - KIRCHMEIER, H. - MUELLER, M. MARX, M. 2012. Controlled traffic farming in Germany - technical and organisational realisation and first results. In International Conference of Agriculture Engineering CIGR - AgEng 2012,Valencia, Spain.

GALAMBOŠOVÁ, J. et al. 2010. Controlled trafic farming and minimum tillage: results of initial experiments and layout of a long-term experiment. In XVII ${ }^{\text {th }}$ World Congress of the International Commission of Agricultural and Biosystems Engineering (CIGR). Retrieved from https://www.bioeng.ca/publications/meetings-pap ers? sobi2Task=sobi2Details\&sobi2ld $=494$

GALAMBOŠOVÁ, J. - RATAJ, V. - VELČICKÝ, L. 2012. Three-year study on soil roughness under the controlled traffic system. In Acta Technologica Agriculturae, vol. 15, no. 2, pp. 38-40.

GALAMBOŠOVÁ, J. - RATAJ, V. 2011. Determination of machinery performance for random and controlled traffic farming. In Precision Agriculture 2011, Prague, pp. 449-456.
GALAMBOŠOVÁ, J. - MACÁK, M. - RATAJ, V. - GODWIN, R. J. ŽITŇÁK, M. - VITÁZKOVÁ, B. - ĎUĎÁK, J. - CHAMEN, T. 2014. Yield performance of controlled traffic farming permanent tramlines. In ASABE Annual International Meeting 2014. St. Joseph, Michigan : ASABE.

HAMZA, M. A. - ANDERSON, W. K. 2005. Soil compaction in cropping systems: A review of the nature, causes and possible solutions. In Soil and Tillage Research, vol. 82, no. 2, pp. 121-145.

CHAMEN, W. C. T. 2011. The effects of low and controlled traffic systems on soil physical properties, yields, and the profitability of cereal crops on a range of soil types. PhD diss. Silsoe, U.K. : Cranfield University.

CHYBA, J. - KROULÍK, M. - LEV, J. - KUMHÁLA, F. 2013. Influence of soil cultivation and farm machinery passes on water preferential flow using brilliant blue dye tracer. In Agronomy Research, vol. 11, no. 1, pp. 25-30.

KINGWELL, R. - FUCHSBICHLER, A. 2011. The whole-farm benefits of controlled traffic farming: An Australian appraisal. In Agricultural Systems, vol. 104, no. 7, pp. 513-521.

KROULÍK, M. - KUMHÁLA, F. - HŮLA, J. - HONZÍK, I. 2009. The evaluation of agricultural machines field trfficking intensity for diffrent soil tillage technologies. In Soil and Tillage Research, vol. 105, no. 1, pp. 171-175.

MAŠEK, J. - NOVÁK, P. - KROULÍK, M. - CHYBA, J. 2012. The quality evaluation of different soil tillage technologies. In Agronomy Research, vol., 12, no. 1, pp. 129-134.

SMITH, E. K. - MISIEWICZ, P. A. - GIRARDELLO, V. - ARSLAN, S. CHANEY, K. - WHITE, D. R. - GODWIN, R. J. 2014. Effects of traffic and tillage on crop yield (winter wheat, Triticum aestivum L.) and the physical properties of a sandy loam soil. ASABE Paper No. 141912652. St. Joseph, Mich. : ASABE.

TULLBERG, J. N. - YULE, D. F. - MCGARRY, D. 2007. Controlled traffic farming - From research to adoption in Australia. In Soil and Tillage Research, vol. 97, no. 2, pp. 272-281.

VERMEULEN, G. D. - TULLBERG, J. N. - CHAMEN, W. C. T. 2010. Controlled traffic farming. In Dedousis, A. P. - Bartzanas, T. (Eds). Soil Engineering. Berlin Heidelberg : Springer - Verlag. 